\title{
PENGARUH PENILAIAN PRESTASI KERJA DAN LOYALITAS KARYAWAN TERHADAP PROMOSI JABATAN
}

\section{THE EFFECT OF EMPLOYEE ACHIEVEMENT AND LOYALTY ASSESSMENT ON POSITION PROMOTION}

\author{
Handayani $^{1}$, St. Hardianti. ${ }^{2}$ \\ Sekolah Tinggi Ilmu Ekonomi Makassar Bongaya, Indonesia \\ Email : sthardiantihamli95@gmail.com
}

(Diterima: 19 November 2020; direvisi: 24 November 2020; dipublikasikan: 07 Desember 2020 )

(C)2018 -Bongaya Journal for Research in Management STIEM Bongaya. Ini adalah artikel dengan akses terbuka dibawah licenci CC BY-NC-4.0 (https://creativecommons.org/licenses/by-nc/4.0/).

Abstract :This study aims to test and analyze Job Performance Appraisal and Employee Loyalty affects Job Promotion at PT PLN (Persero) UP3 North Makassar ULP Karebosi. Data collection using primary data obtained from questionnaires using total sampling technique. The population is all 36 employees of PT PLN (Persero) UP3 Makassar Utara ULP Karebosi. The samples taken were all employees totaling 36 people. The results of the questionnaire have been tested for validity and reliability, as well as tested for classical assumptions in the form of normality test, multicollinearity test and heteroscedasticity test. Methods of data analysis using Multiple Linear Regression techniques. Based on the results of the study, it shows that the first hypothesis is accepted because it shows a positiveand significant hypothesis test results, this means that the Job Performance Assessment hasa positive and significant effect on Job Promotion. The second hypothesis is accepted because it shows positive and significant hypothesis test results, this means that Employee Loyalty has a positive and significant effect on Job Promotion. The third hypothesis shows that Job Performance Appraisal is the dominant variable, this means that Job Performance Assessment has a greater contribution than Employee Loyalty to Job Promotion.

Keywords: Work Performance; Loyalty; Job Promotion; Employee

\begin{abstract}
Abstrak : Penelitian ini bertujuan untuk menguji dan menganalisis penilaian prestasi Kkrja dan loyalitas pegawai berpengaruh terhadap Promosi Jabatan pada PT PLN (Persero) UP3 ULP Makassar Utara Karebosi. Pengumpulan data menggunakan data primer yang diperoleh dari kuesioner dengan menggunakan teknik total sampling. Populasi dalam penelitian ini adalah seluruh 36 karyawan PT PLN (Persero) UP3 Makassar Utara ULP Karebosi. Sampel yang diambil adalah seluruh karyawan yang berjumlah 36 orang. Hasil angket telah diuji validitas dan reliabilitasnya, serta diuji asumsi klasik berupa uji normalitas, uji multikolinearitas dan uji heteroskedastisitas. Metode analisis menggunakan teknik Regresi Linier Berganda. Berdasarkan hasil penelitian menunjukkan bahwa hipotesis pertama diterima karena menunjukkan hasil uji hipotesis yang positif dan signifikan, artinya penilaian prestasi kerja berpengaruh positif dan signifikan terhadap promosi jabatan. Hipotesis kedua diterima karena menunjukkan hasil uji hipotesis yang positif dan signifikan, artinya loyalitas karyawan berpengaruh positif dan signifikan terhadap promosi kerja. Hipotesis ketiga menunjukkan bahwa penilaian kinerja memiliki kontribusi yang lebih besar daripada loyalitas karyawan terhadap promosi jabatan
\end{abstract}

Kata kunci: Prestasi Kerja; Loyalitas; Promosi Jabatan; Karyawan 


\section{PENDAHULUAN}

Persaingan antar perusahaan di era globalisasi semakin tajam, sehingga perusahaan dituntut untuk terus-menerus mengembangkan SDM yang dimiliki secara proaktif, sehingga potensi mereka berkembang secara maksimal. Pendapat yang sama juga dinyatakan oleh Voon $e t$ al (dalam Aprisal 2019) "bahwa karyawan merupakan aset paling penting bagi organisasidan organisasi harus memiliki pemimpin yangmampu memimpin dan memotivasi karyawan untuk mencapai tujuan organisasi" perusahaan dituntut secara terus-menerus bersaing dan mengembangkan diri.

Pengembangan sumber energi manusia bisa dicoba dengan bermacam metode, salah satunya merupakan dengan lewat promosijabatan. Promosi jabatan adalah fasilitas yang bisa mendesak karyawan buat lebih baik ataupun lebih bergairah dalam melaksanakan sesuatupekerjaan dalam sesuatu area industri. Tata kelola pengangkatan jabatan berdasarkan penjelasan PER-02/MBU/10/2019 tentang Manajemen Karier Pegawai Negeri Sipil di Lingkungan Kementerian BUMN adalah untuk pengangkatan dalam jabatan struktural berdasarkan rekomendasi Tim Penilai Kinerja PNS, rekomendasi diusulkan berdasarkan persyaratan pengangkatan dalam jabatan. Tim Penilai Kinerja PNS merekomendasikan kandidatpaling sedikit 3 (tiga) orang untuk diajukan kepada Pejabat Pembina Kepegawaian (PPK). Sedangkan jabatan fungsional untuk kenaikan pangkatnya menggunakan angka kredit atau metode penilaian lainnya sebagaimana diatur sesuai ketentuan jabatan fungsional terkait. Pendeglasian dalam pengangkatan jabatan fungsional berdasarkan Pasal 86 Peraturan Pemerintah Nomor 11 Tahun 2017 adalah "Pejabat Pembina Kepegawaian (PPK) dapat memberikan kuasa kepada pejabat yang ditunjuk di lingkungannya untuk menetapkan pengangkatan dalam jabatan fungsional selain jabatan fungsional ahli madya"

$\begin{array}{ccr}\text { Dengan adanya } & \text { promosi jabatan, } \\ \text { karyawan akan } & \text { merasa lebih }\end{array}$
dihargai,.diperhatikan,. dibutuhkan serta diakui kemampuan kerjanya oleh manajer akan menghasilkan keluaran (output) yang tinggi (Veitzal, (2011), Nur Rahmi (2019)).

Bagi manajer, promosi jabatan yang diberikan kepada karyawan sebagai reward atas kinerja yang dilakukan oleh karyawan dalam melaksanakan tanggung jawabnya. Bagi perusahaan, promosi jabatan bertujuan untuk meregenerasi sumber daya manusia yang dimiliki demi kelangsungan perusahaan tersebut (Nawawi, 2009). Menurut PP No. 11 Tahun 2017 tentang Manajemen PNS penilaian prestasi kerja adalah termasuk salah satu persyaratan pengangkatan jabatan di BUMN

Karyawan yang memiliki prestasi kerja yang baik dapat diketahui setelah karyawan melaksanakan tugas-tugas yang dibebankan kepadanya sesuai dengan standar yang ditetapkan, sehingga perusahaan dapat "menetapkan kebijaksanaan berarti apakah karyawan akan dipromosikan, didemosikan, dan atau balas jasanya dinaikkan" Hasibuan (2016). Penilaian prestasi kerja mengacu pada PPNo. 46 Tahun 2011 tentang Penilaian Prestasi Kerja PNS.

Disisi lain, loyalitas karyawan juga dapat menentukan promosi jabatan, karyawan yang masa kerjanya paling lama adalah karyawan yang paling berhak untuk dipromosikan jabatannya. Permasalahan dalam melaksanakan promosi jabatan juga tidak akan lepas dari sejauh mana loyalitas kerja karyawan terhadap perusahaan (Aryani, dkk. 2010). Hasibuan (2016) menjelaskan bahwa "loyalitas atau kesetiaan terhadap perusahaan tempat bekerja sering dipakai sebagai syarat untuk promosi, hal ini disebabkan dengan loyalitas yang tinggi dapat diharapkan tanggung jawab yang lebih besar".

Permasalahan yang muncul terkait dengan sistem promosi jabatan saat ini adalah terletak pada proses evaluasi untuk mempromosikan seseorang, dimana karyawan dipromosikan ke jabatan yang lebih tinggi dengan hanya melihat dari satu kriteria penilaian, yang pada kenyataannya karyawan tersebut belum tentu unggul pada beberapa kriteria lainnya (Siagian, 2014). Di perusahaan BUMN "Pengembangan karier, pengembangan kompetensi, pola karir, mutasi, dan promosi merupakan manajemen karier PNS yang harus dilakukan dengan menerapkan prinsip Sistem Merit" Pasal 162 PP No. 11 Tahun 2017 tentang Manajemen PNS

"Sistem Merit adalah kebijakan dan Manajemen ASN yang berdasarkan pada kualifikasi, kompetensi dan kinerja secara adildan wajar dengan tanpa membedakan latar belakang politik, ras, warna kulit, agama, asal usul, jenis kelamin, status pernikahan, umur, atau kondisi kecacatan." Pasal 1 PP Nomor 11 Tahun 2017 tentang Manajemen PNS. 
Berdasarkan fakta lapangan yang sering terjadi pada PT PLN (Persero) UP3 Makassar Utara ULP Karebosi bahwa penilaian promosi jabatan karyawan sulit diterapkan secara objektif dan adil karena adanya unsur nepotisme, faktor sosial dan persahabatan. Melakukan promosi jabatan bukan berdasarkan kualifikasi, kompetensi dan kinerja (penilaian prestasi kerja) ataupun loyalitas tetapi hanya karena keakraban serta balas budi, siapa yang lebih dekat dengan atasannya akan diseleksi walaupun masih ada karyawan lain yang sudah memenuhi persyaratan yang berlaku sesuai peraturan untuk dapat dipromosikan.

Terkait aspek kinerja yang dimaksud, kinerja adalah semua unsur penilaian prestasi kerja sekurang-kurangnya bernilai baik dalam 2 (dua) tahun terakhir di unit penempatan sebelumnya dan penilaian kinerja penugasan dengan kategori baik dan untuk aspek pengalaman kerja adalah seberapa lama pegawai tersebut berpengalaman bekerja di jabatan tertentu.

Berdasarkan peraturan pemerintah dan menteri, penilaian prestasi kerja (kinerja) dan tingkat loyalitas dapat mempengaruhi promosi jabatan selain kompetensi dan potensi karyawan serta aturan yang lainnya. Namun berdasarkan fakta lapangan yang terjadi dalam menentukan promosi jabatan perusahaan tidak memperhatikan hal-hal tersebut.

Sebelum dilakukan promosi jabatan karyawan akan mengikuti diklat penjenjang terdahulu. Diklat penjenjang sendiri merupakan pendidikan dan pelatihan yang diberikan semua pegawai yang ingin mengembangkan pola karirnya yang berkaitan dengan pemenuhan level kompetensi dan kebutuan kompetensi jabatan.

Guna pendidikan diklat tersebut untuk menaikkan grade peringkat karyawan. Fakta lain yang terjadi pada PT PLN (Persero) UP3 Makassar Utara ULP Karebosi ditemukan bahwa tingginya grade peringkat (grade peringkat dalam PLN disebut sistem, semakin rendah sistem maka semakin tinggi jabatan karyawan) tidak menjadi faktor seseorang memiliki jabatan, akibatnya terdapat beberapa karyawan yang bekerja bertahun-tahun namun tidak terlibat dalam jenjang dan pengembangan karir seperti promosi jabatan di dalam perusahaan. Namun karyawan tersebut tetap naik peringkat ke golongan yang lebih tinggi minimal 1 sampai 3 tahun sekali sesuai ketentuan perusahaan, untuk karyawan yang ingin dipromosikan tiap tahun di naikkan grade peringkatnya.
Berdasarkan penelitian terdahulu yang menganalisis pengaruh penilaian prestasi kerjadan loyalitas karyawan terhadap promosi jabatan, ditunjukkan pada studi yang dilakukan Sutanto \& Perdana (2016) bahwa penilaian prestasi kerjadan loyalitas karyawan secara simultan berpengaruh signifikan terhadap promosi jabatan. Penelitian terdahulu yang menganalisis pengaruh prestasi kerja dan loyalitas terhadap promosi jabatan, ditunjukkan pada studi yang dilakukan Data \& Tafsir (2018), Sidik (2016) bahwa terdapat pengaruh positif dan signifikan prestasi kerja dan loyalitas terhadap promosi jabatan. Penelitian terdahulu yang menganalisis pengaruh penilaian prestasi terhadap promosi jabatan, ditunjukkan pada studi yang dilakukan Simbolon (2015) menunjukkan bahwa penilaian prestasi kerja berpengaruh positif dan signifikanterhadap promosi jabatan.

Penelitian ini dilakukan di PT PLN (Persero) Area Makassar Utara yang merupakan Badan Usaha Milik Negara (BUMN) bergerak pada bidang penyediaan listrik untuk masyarakat. Dengan pertimbangan instan bahwa promosi ialah tolak ukur kemajuan oleh seorang pegawai dalam melakukan tugasnya, sehingga perihal ini merupakan sesuatu permasalahan untukpimpinan yang wajib diperhatikan serta dijalankan sesuai peraturan yang berlaku dan promosi juga merupakan salah satu usaha pengembangan yang sangat diharapkan untuk kestabilan suatu organisasi khususnya di lingkungan PT PLN (Persero) Area Makassar Utara.

Berdasarkan fakta lapangan yang dijelaskan diatas serta teori konsep, peraturan yang berlaku dan penelitian terdahulu dalam menjelaskan pengaruh antar variabel dalam penelitian ini, hingga peneliti tertarik melaksanakan penelitian dengan judul"Pengaruh Penilaian Prestasi Kerja dan Loyalitas Karyawan terhadap PromosiJabatan pada PT PLN (Persero) UP3 Makassar Utara ULP Karebosi”.

\section{METODE}

Populasi adalah kumpulan dari semua kemungkinan orang- orang, benda- benda, dan ukuran lain, yang menjadi objek perhatian atau kumpulan seluruh objek yang menjadi perhatian (Suharyadi dan Purwanto, 2009). Berdasarkan pernyataan tersebut, populasi dari penelitian ini adalah karyawan PT PLN (Persero) UP3 
Makassar Utara ULP Karebosi yang jumlahnya sebanyak 36 orang pegawai.

Menurut Suharyadi dan Purwanto (2009) Sampel adalah suatu bagian dari populasi tertentu yang menjadi perhatian. Teknik pengambilan sampel yang digunakan dalam penelitian ini adalah teknik total sampling yaitu teknik pengambilan sampel yang tidak memerlukan prosedur seleksi terlebih dahulu, tetapi menggunakan penilaian personal dari penelitian atau yang menggunakan seluruh anggota populasi sebagai sampel (Sugiyono, 2012). Sehingga jumlah sampel dalam penelitian ini yaitu sebanyak 36 orang karyawan.

Teknik pengumpulan informasi yang digunakan oleh riset ini adalah melalui kuesioner ataupun catatan statement lewat online. Selainitu, wawancara dilakukan disaat riset pendahuluan untuk mendapatkan permasalahan yang wajib diteliti serta digunakan untuk mengenali hal-hal yang diduga berarti yang tidakdapat dijelaskan melalui kuesioner penelitian seperti faktor penyebab positif atau negatif dan signifikan atau tidak signifikan hasil temuan penelitian yang dilakukan dengan mengadakan tanya jawab kepada responden.

Populasi statisik ini akan cocok digunakan bila sampel diambil dari populasi yang jelas dan teknik pengambilan sampel dari populasi itu dilakukan secara random (Sugiyono, 2012).

Penelitian ini menggunakan multiple linear regression yang digunakan untuk mengenali arah hubungan antara variabel independent dan dependen apakah positif ataupun negatif serta Statistik deskriptif membagikan gambaran universal tentang objek riset yang dijadikan ilustrasi. Penjelasan data lewat statistik deskriptif diharapkan membagikangambaran dini tentang permasalahan yang diteliti. Penelitian ini menggunakan statistikdeskriptif yang terdiri dari minimum, maksimum, mean dan deviasi standar. Statistik inferensial adalah teknik statistik yang digunakan8untuk menganalisis data sampel dan hasilnya diberlakukan untuk untuk memprediksi nilai dari variabel dependen apabila nilai variable independen mengalami peningkatan ataupun penurunan.

\section{HASIL DAN PEMBAHASAN}

Penelitian ini menggunakan multiple linear regression yang digunakan untuk mengetahui arah hubungan antara variabel independen dengan variabel dependen apakah positif atau negative dan untuk memprediksi nilai dari variabel dependen apabila nilai variabel independen mengalami kenaikan atau penurunan.

Dalam penelitian ini variabel yang digunakan adalah penilaian prestasi kerja $\left(\mathrm{X}_{1}\right)$ dan loyalitas karyawan $\left(\mathrm{X}_{2}\right)$ sebagai variabel independen terhadap promosi jabatan (Y) sebagai variabel dependen. Hasil regresi linear berganda berdasarkan pengolahan data menggunakan IBM SPSS 22 adalah sebagai berikut :

Tabel 1 : Hasil uji regresi linear berganda

\begin{tabular}{l|l|l|l}
\hline Model & $\begin{array}{l}\text { Unstandirized } \\
\text { Coefficient }\end{array}$ & $\mathrm{t}$ & sig \\
\cline { 2 - 3 } & $\mathrm{B}$ & & \\
\hline Constan & 9.374 & 3.662 & .001 \\
Pres kerja & .865 & 3.568 & .001 \\
Layalitas & .656 & 2.663 & .012 \\
\hline
\end{tabular}

a. Dependent Variable : Promosi Jabatan Sumber : Output IBM SPSS 22 (2020)

Berdasarkan tabel 1 dapat diketahui nilai koefisien regresi penilaian prestasi kerja $\left(\mathrm{X}_{1}\right)$ dan loyalitas karyawan $\left(\mathrm{X}_{2}\right)$ terhadap promosi jabatan $(\mathrm{Y})$, masing-masing sebesar $0,865\left(\mathrm{X}_{1}\right), 0,656\left(\mathrm{X}_{2}\right)$ dan nilai constant sebesar 9,374. Dengan demikian terbentuk persamaan multiple linear regression sebagai berikut :

\section{$Y=9,374+0,865 X_{1}+0,656 X_{2}$}

Model ini menunjukkan bahwa koefisien regresi hasil taksiran $X_{1}$ dan $X_{2}$ bertanda positif. Hasil ini memberikan gambaran bahwa adanya hubungan positif dari variabel penilaian prestasi kerja dan loyalitas karyawan terhadap promosi jabatan, yang berarti bahwa semakin meningkatnya penilaian prestasi kerja dan loyalitas karyawan maka akan meningkatkan promosi jabatan. Berdasarkan persamaan di atas dapat dijelaskan sebagai berikut :

(1) Variabel penilaian prestasi kerja $\left(\mathrm{X}_{1}\right)$ memiliki koefisien regresi positif sebesar 0,865 berarti apabila penilaian prestasi kerja naik $1 \%$ maka promosi jabatan akan mengalami kenaikan sebesar $0,865 \%$ pada saat variabel lainnya tidak berubah (konstan).

(2) Variabel loyalitas karyawan $\left(\mathrm{X}_{2}\right)$ memliki koefisen regresi positif 0,656 berarti apabila loyalitas karyawan naik $1 \%$ maka promosi jabatan akan mengalami kenaikan sebesar $0,656 \%$ pada saat variabel lainnya tidak berubah (konstan). 
(3) Kemudian koefisien regresi berganda untuk konstan sebesar 9,374, artinya pada saat variabel penilaian prestasi kerja dan loyalitas karyawan sama dengan nol (0) maka besarnya promosi jabatan $9,374 \%$.

\section{Pengujian Hasil Hipotesis \\ Hasil Pengujian Simultan (Uji F/Fisher)}

Uji $F$ untuk menguji apakah penilaian prestasi kerja dan loyalitas karyawan secara bersama-sama memiliki pengaruh signifikan terhadap promosi jabatan.

\section{Kriteria pengujian dua sisi:}

Jika $\mathrm{F}_{\text {hit }}>\mathrm{F}_{\text {tab }}$ : maka $\mathrm{H}_{\mathrm{a}}$ diterima $\mathrm{H}_{\mathrm{o}}$ ditolak, dan atau model dinyatakan layak (memenuhi uji kesesuaian model/goodness of fit model

Jika $\mathrm{F}_{\text {hit }}<\mathrm{F}_{\text {tab }}$ : maka $\mathrm{H}_{\mathrm{o}}$ diterima $\mathrm{H}_{\mathrm{a}}$ ditolak, dan atau model dinyatakan layak (memenuhi uji kesesuaian model/goodness of fit model).

Berikut ini adalah tabel hasil pengujian simultan penelitian :

\section{Tabel 2 : Hasil Pengujian Simultan (Uji}

F/Fisher)

\begin{tabular}{l|l|l|l}
\hline Model & $\begin{array}{l}\text { Sum of } \\
\text { Squares }\end{array}$ & f & Sig \\
\hline Regresion & 164.157 & 27.612 & $.000^{\mathrm{b}}$ \\
\hline Residual & 98.093 & & \\
\hline Total & 262.25 & & \\
\hline \multicolumn{2}{c}{ Sumber : Output IBM SPSS 22 (2020) }
\end{tabular}

Berdasarkan tabel 2 dimana nilai $F_{\text {hit }}$ sebesar 27,830 dengan nilai df1 dan df2 $=2,33$, maka diperoleh nilai $F_{\text {tab }}$ sebesar 3,285. Nilai ini dapat dicari di MsExcel dengan cara pada sel kosong ketik $=\mathrm{FINV}(0.05,2,33)$ lalu enter .

Oleh karena itu $\mathrm{F}_{\text {hit }}$ 27,612 lebih besar dibanding $\mathrm{F}_{\mathrm{tab}}$ 3,285 maka dengan derajat kekeliruan $5 \%(\alpha=0,05)$ maka $\mathrm{H}_{\mathrm{a}}$ diterima $\mathrm{H}_{\mathrm{o}}$ ditolak (hipotesis diterima) dan dengan nilai signifikan $0.000<0.05$. Artinya dengan tingkat kepercayaan $95 \%$ dapat dikatakan bahwa penilaian prestasi kerja $\left(\mathrm{X}_{1}\right)$ dan loyalitas karyawan $\left(\mathrm{X}_{2}\right)$ secara simultan berpengaruh signifikan terhadap promosi jabatan (Y) pada PT. PLN (Persero) UP3 Makassar Utara ULP Karebosi.

\section{Hasil Pengujian Parsial (Uji t/student)}

Selanjutnya untuk mengetahui koefisien regresi variabel bebas mana yang pengaruhnya signifikan maka dilakukan uji koefisien regresi secara individual (parsial). Kriteria pengujian dua pihak jika $t_{\text {hitung }}>t_{\text {tabel }}$ maka $H_{o}$ ditolak dan
$\mathrm{H}_{\mathrm{a}}$ diterima, pada tingkat signifikan $\alpha=0,05$ dan derajat kebebasan (df).

Untuk mengetahui nilai $t_{\text {tabel }}$ dengan tingkat signifikan $\alpha=0,05$ dan derajat bebas (df) $=33$ maka $t_{\text {tabel }}$ yang diperoleh pada lampiranyaitu sebesar 2,035. Nilai ini dapat dicari di MsExcel dengan cara pada sel kosong ketik $=\operatorname{TINV}(0.05,33)$ lalu enter .

Berdasarkan tabel 1 dapat diketahui pengaruh masing-masing variabel independen yang terdiri atas penilaian prestasi kerja dan loyalitas karyawan terhadap variabel dependen yaitu promosi jabatan dijelaskan sebagai berikut:

(1) Pengaruh Penilaian Prestasi Kerja $\left(X_{1}\right)$ terhadap Promosi Jabatan (Y).

Hasil penelitian penilaian prestasi kerja $\left(\mathrm{X}_{1}\right)$ terhadap promosi jabatan (Y) diperoleh data yakni thitung 3.568 Lebih besar dari $t_{\text {tabel }} 2,035$, maka pada tingkat kekeliruan $5 \% \mathrm{H}_{\mathrm{o}}$ ditolak dan $\mathrm{H}_{\mathrm{a}}$ diterima (hipotesis diterima) dan dengan nilai signifikan 0,002 >0,05 artinya signifikan. Maka dapat dikatakan bahwa penilaian prestasi kerja $\left(\mathrm{X}_{1}\right)$ secara parsial berpengaruh positif dan signifikan terhadap promosi jabatan (Y).

(2) Pengaruh Loyalitas Karyawan(X2) terhadap Promosi Jabatan (Y)

Hasil penelitian loyalitas karyawan $\left(\mathrm{X}_{2}\right)$ terhadap promosi jabatan (Y) diperoleh data yakni thitung 2.663Lebih besar dari $t_{\text {tabel }} 2,035$, maka pada tingkat kekeliruan $5 \% \mathrm{H}_{\mathrm{o}}$ ditolak dan $\mathrm{H}_{\mathrm{a}}$ diterima (hipotesis diterima) dan dengan nilai signifikan 0,009>0,05 artinya signifikan. Maka dapat diidentifikasi bahwa loyalitas karyawan $\left(\mathrm{X}_{2}\right)$ secara parsial berpengaruh positif dan signifikan terhadap promosi jabatan (Y).

\section{Analisis Determinasi}

\section{Uji Determinasi Secara Parsial $\left(r^{2}\right)$}

Koefesien determinasi $r^{2}$ menunjukkan besarnya pengaruh variabel independent secara parsial terhadap variable dependen. Untuk mengetahui variabel mana diantara penilaian prestasi kerja dan loyalitas karyawan yang memberi kontribusi yang besar dalam mempengaruhi promosi jabatan. Maka perlu dihitung terlebih dahulu nilai pearson correlation. Hasil uji nilai koefisien korelasi pada tabel berikut :

Nilai koefisien korelasi penilaian prestasi kerja $\left(\mathrm{X}_{1}\right)$ dengan promosi jabatan sebesar 0,739 dan loyalitas karyawan $\left(\mathrm{X}_{2}\right)$ dengan promosi jabatan sebesar 0,694. Hasil tersebut digunakan 
untuk menghitung kontribusi dari masing-masing variabel independen, untuk itu ditunjukkan pada tabel berikut:

\section{Tabel 3 : Koefisien Determinasi $\mathbf{r}^{2}$}

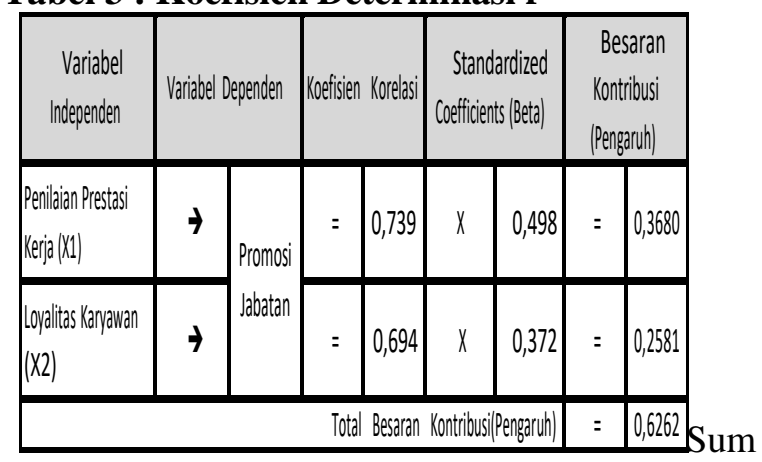

ber : Data diolah dari hasil penelitian (2020)

Berdasarkan tabel 3 diperoleh koefisien determinasi $\mathrm{r}^{2}$ yaitu penilaian prestasi kerja $\left(\mathrm{X}_{1}\right)$ memberikan kontribusi terhadap promosi jabatan sebesar 0,3680 atau $36,80 \%$, sedangkan loyalitas karyawan $\left(\mathrm{X}^{2}\right)$ memberikan kontribusi sebesar 0,2581 atau $25,81 \%$. Berdasarkan hasil tersebut bahwa variabel penilaian prestasi kerja berpengaruh dominan terhadap promosi jabatan.

\section{Uji Determinasi Secara Simultan $\left(\mathbf{R}^{2}\right)$}

Berdasarkan hasil determinasi $r^{2}$, dapat juga dijelaskan pengujian koefisien determinasi yang dilandasi dari nilai kontribusi $36,80 \%$ dari variabel (X1) dan $25,81 \%$ dari variabel (X2) dengan total berjumlah $62,6 \%$ atas semua kontribusi variabel bebas yang diteliti terhadap variabel terikat.

Dalam pengujian koefisien determinasi dilihat dari besarnya nilai $R$ Square $\left(\mathrm{R}^{2}\right)$ untuk mengetahui besarnya pengaruh variabel penilaian prestasi kerja dan loyalitas secara bersama-sama terhadap variabel promosi jabatan. Nilai $\mathrm{R}^{2}$ yang semakin mendekati angka 1 menunjukkan bahwa pengaruh variabel independen terhadap variabel dependen semakin besar. Hasil uji determinasi $\mathrm{R}^{2}$ pada table berikut:

Tabel 4: Hasil pengujian determinasi $\left(\mathbf{R}^{2}\right)$

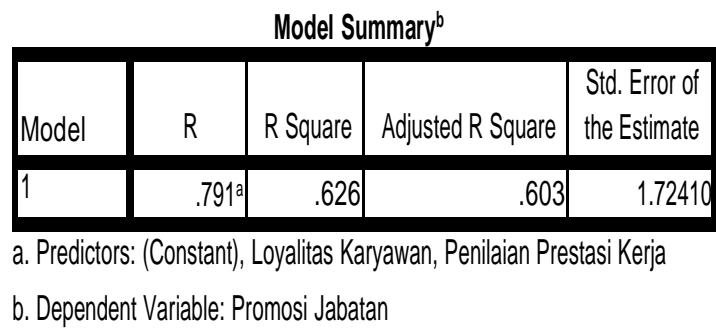

Sumber: Output IBM SPSS 22 (2020)

Berdasarkan tabel 4 menunjukkan hasil $\mathrm{R}^{2}$ yaitu sebesar 0,626 atau $62,6 \%$ besarnya promosi jabatan yang dipengaruhi oleh variabel penilaian prestasi kerja dan loyalitas karyawan. Sedangkan 37,4\% promosi jabatan dipengaruhi oleh variabel diluar penelitian yang dilakukan seperti variabel kompetensi, potensi, pengalaman kerja, kualitas pendidikan dan senioritas.

\section{SIMPULAN DAN SARAN}

\section{Kesimpulan}

Berdasarkan hasil penelitian yang dilakukan tentang "pengaruh penilaian prestasi kerja dan loyalitas karyawan terhadap promosi jabatan pada PT. PLN (Persero) UP3 Makassar Utara ULP Karebosi” yang dimaksudkan untuk menjawab pertanyaan dari rumusan masalah yang telah dikemukakan, maka dapat ditarik kesimpulan sebagai berikut

1.) Berdasarkan analisis secara parsial (Uji t/student), menunjukkan bahwa variabel independen, yaitu Penilaian Prestasi Kerja $\left(\mathrm{X}_{1}\right)$ berpengaruh positif dan signifikan terhadap Promosi Jabatan (Y) pada PT. PLN (Persero) UP3 Makassar Utara ULP Karebosi, maka dinyatakan hipotesis pertamaditerima.

2.) Berdasarkan analisis secara parsial (Uji t/student), menunjukkan bahwa variabel independen, yaitu Loyalitas Karyawan $\left(\mathrm{X}_{2}\right)$, berpengaruh positif dan signifikan terhadap Promosi Jabatan (Y) pada PT. PLN (Persero) UP3 Makassar Utara ULP Karebosi, maka dinyatakan hipotesis kedua diterima.

3.) Berdasarkan pengujian korelasi, menunjukkan bahwa variabel Penilaian Prestasi Kerja $\left(\mathrm{X}_{2}\right)$ berpengaruh dominan terhadap Promosi Jabatan (Y) pada PT. PLN (Persero) UP3 Makassar Utara ULP Karebosi.

\section{Saran}

Bersumber pada kesimpulan telah diperoleh dalam riset ini, maka diberikan saran untuk tambahan terhadap hasil riset yang bisa diberikan sebagai berikut:

1.) Bagi Instansi

a.) Agar kiranya industri menerapkan evaluasi prestasi kerja dengan metode terangterangan ataupun terbuka serta menyampaikan maksud serta tujuannya agar karyawan bisa berpartisipasi, mendukung dan turut serta dalam proses evaluasi, dengan evaluasi ini sehingga tidak terdapat lagi kecemburuan sosial yang muncul oleh karyawan. Senantiasa 
mengacu pada. Prinsip evaluasi prestasi kerja PNS bersumber pada Pasal PP Nomor 46 Tahun 2011 tentang Evaluasi Prestasi Kerja Pegawai Negara Sipilyaitu evaluasi prestasi kerja yang objektif, terukur, akuntabel, partisipatif dan transparan.

b.) Untuk pengembangan karier, pola karier, dan promosi agar kiranya perusahaan menerapkan prinsip Sistem Merit sesuai dengan Pasal 162 PP Nomor 11 Tahun 2011 tentang Manajemen Pegawai Negeri Sipil "Sistem Merit adalah kebijakan dan Manajemen ASN yang berdasarkan pada kualifikasi, kompetensi dan kinerja secara adil dan wajar dengan tanpa membedakan latar belakang politik, ras, warna kulit, agama, asal usul, jenis kelamin, status pernikahan, umur, atau kondisi kecacatan."

\section{DAFTAR RUJUKAN}

Agustini, Fauzia. (2011). Manajemen Sumberdaya Manusia Lanjutan. Medan: Madenatera.

Aprisal, (2019). Pengaruh Motivasi Dan Lingkungan Kerja Terhadap Kinerja Pegawai Pada Kantor Kecamatan Panakkukang. : Bongaya Journal for Research in Management, Vol 2v No.2

Aryani, Y., Dhewi, R.M., dan Mangkuprawira, S. (2010). Analisis Pengaruh Sistem Promosi Jabatan terhadap Kinerja Karyawan pada Divisi Human Resources and General Affairs PT Indocement Tunggal Prakarsa, Tbk Citeureup. Jurnal Manajemen dan Organisasi, 1(3): h:171186

Byars, Lloyd L dan Leslie W. Rue (2000). Human ResourcesManagement, Interna tional Edition. New York USA : IrwinMcGraw-Hill.

Data, \& Tafsir (2018).Pengaruh Kepemimpinan, Motivasi Dan Budaya Organisasi Terhadap Kinerja PegawaiSeiko: Journal of Management \& Business,

Hasibuan, Malayu. (2016). Manajemen Sumber Daya Manusia, Cetakan Kesembilan belas. Jakarta: PT Bumi Aksara

Hamzah, F.M., Musadieq, M.A., dan Hakam, M.S. (2013). Pengaruh Senioritas dan Loyalitas kerja Terhadap Promosi Jabatan (Studi Pada Karyawan PT pembangunan Perumahan DVO III Surabaya). Jurnal Administrasi Bisnis $(J A B), 6(2)$.

Nawawi, Hadari. (2009). Manajemen Sumber Daya Manusia Untuk Bisnis Yang Kompetitif, Cetakan Ke-4. Yogyakarta : Gajah Mada Univercity Press.

Nur Rahmi, (2019).Pengaruh pelatihan gaya kepemimpinan dan disiplin kerja terhadap kinerja karyawan pt.Perkebunan nusantara xiv (persero) makassar. : Bongaya Journal for Research in Management, $\mathrm{Vol} 2 \mathrm{v}$ No.1

Peraturan Pemerintah 46 Tahun 2011 tentang Penilaian Prestasi Kerja Pegawai Negeri Sipil

Peraturan Pemerintah Nomor 11 Tahun 2017 tentang Manajemen Pegawai Negeri Sipil.

PER-02/MBU/10/2019 tentang Manajemen Karier Pegawai Negeri Sipil di Lingkungan Kementerian Badan Usaha Milik Negara.

R.wayne Mondy, Manajemen Sumber Daya Manusia, Edisi Ke Sepuluh Jilid I, Erlangga: Jakarta, 2008.

Siagian, Sondang P. (2014). Manajemen Sumber Daya Manusia. Cetakan kedua puluh dua. Jakarta: Bumi Aksara

Sugiyono. (2012). Metode Penelitian Bisnis. Bandung: Alfabeta.

Sidik, R. (2016). Pengaruh Loyalitas Dan Motivasi Terhadap Produktivitas Karyawan Pada Wahid Galeri Seni Ukir. Universitas Bina Darma.

Simbolon, Hotma B.R. (2015). Pengaruh Motivasi Terhadap Loyalitas Kerja Karyawan Bagian Marketing pada PT.Agung Automall Cabang Pekanbaru. Jurnal. Jurusan Adiminstrasi Bisnis Universitas Riau No. 2 Vol. 1.

Sutanto, E. M., \& Perdana, M. (2016). Antecedents variable of em-ployee loyalty. Jurnal Manajemen dan Kewirausahaan, 18(2), 113

Veithzal Rivai. (2011). Manajemen Sumber Daya Manusia Untuk Perusahaan Dari Teori ke Praktik. Jakarta : Kencana. 